\title{
Students' Perceptions on the Use of Story Maps in Reading Comprehension
}

\author{
${ }^{1}$ Vira Oktaviana, ${ }^{2}$ Zainul Aminin \\ Universitas Negeri Surabaya \\ *Corresponding Author \\ Email: vira.17020084022@mhs.unesa.ac.id
}

\begin{abstract}
Students need to have good reading comprehension in the classroom to have critical skills for studying academic material. However, many students in Indonesia still have difficulty understanding the text. Students can use an appropriate strategy such as story maps to help them understand the text. This research aims to know students' perceptions on the use of story maps in reading comprehension, the advantages, and difficulties of using story maps for students' reading comprehension in class. This research was conducted on the students of tenth grade at one senior high school in Lamongan. The instruments in this study were a questionnaire and interview. The research design of this study used a qualitative research design. The technique to analyze the data were data reduction, data display, and conclusion drawing. The results show that story maps can help the students in understanding the text. Most students felt that they had an improvement in reading comprehension because they thought it easy and fast to understand the text. Story maps also help the students understand the text structure, and it was also an exciting activity. Besides that, the students also faced difficulties when using story maps, such as difficulty making the story maps, not understanding the concept of story maps, and difficulty understanding the content of the text, so they have problems in making story maps.
\end{abstract}

Keywords: tenth graders, story maps, reading comprehension

\section{INTRODUCTION}

Reading is the main activity in teaching and learning success for all educational stages because all the materials used in teaching and learning are written. Therefore, the need for reading and understanding the text is essential. There are two main things involved in reading: the first is finding and understanding the written symbols (words); the next step is to clear the way for interpretation and internalization of meaning (Qanwal \& Karim, 2014). First, the reader reads the text dynamically and tries to get the meaning of the text being read, then receives a message conveyed from the author with the text.

Knowing how to read is called reading or reading ability; the latter is differentiated as reading comprehension or comprehension skills. Reading comprehension is a complex cognitive process (Meniado, 2016). It consists of various components, processes, and factors involved in multiple situations to find better ways of developing it among learners. Learners should understand the main idea, important details, and all the meaning of the text. Qanwal \& Karim (2014) state that reading comprehension is a critical learning skill for several reasons. By having this skill, a person can understand what the author means and then build the meaning from the text read. Students need to have good reading comprehension to extract all the information from the text. Jalilehvand (2012) argues that if students have good reading comprehension, they also can process all the knowledge better. 
The better students' reading comprehension, the better they will be at mastering other subjects.

Khodabandehlou et al. (2014) argue that students in the classroom often face trouble when they comprehend a text. They only focus on finding the accurate answer then forget the process of finding the answer. They focus on the dictionary to check every unfamiliar word. Therefore, the process of understanding the text is difficult to do and makes the teaching-learning process will be disrupted. According to the problem, the teacher's job is to help students to make students' reading comprehension increase. The teacher can provide creative ways to make students interested to understand the text. As reviewed by Isikdogan \& Timurtas (2010), instructional media can help students improve their reading comprehension. Students will have good reading comprehension by using an excellent and appropriate strategy.

Students can get many visual media to support their learning process in a modern era, such as computers, videos, etc. There are also many pictures and photographs in the classroom. Sam \& Rajan (2013) state that these tools can be used as media to understand a text. Besides that, they also don't need a long time to understand materials and save their time. Teachers can help students to choose the appropriate media that they will use. They can help students to improve their reading comprehension by using a Graphic Organizer. Graphic organizer is a graphic that symbolizes a correlation of a text created after reading the information (Sam \& Rajan, 2013). It can be used as an alternative media in reading because it is effective, and students can classify the material or information they have read into a diagram. Students could develop their critical and creative thinking elements after reading the passage by using the graphic organizer.

Graphic organizers come in several different forms: story maps, concept maps, tree diagrams, Venn diagrams, etc. Story maps is a graphic organizer that is sometimes used in narrative texts. Manoli \& Papadopoulou (2012) define that story maps as one of the graphic organizers often used in narrative texts. It attracts students' attention because students can put vital information such as characters, setting, plot, and time in a specific place. The use of story maps aims to help students make story concepts related to components in the story based on students' minds. It can help students develop their thinking skills to understand the text through the story. Students can have a better understanding of reading a text by using this strategy.

According to Isikdogan \& Kargin (2010), there are four stages in using story maps in class for teaching reading. The first is modeling. During this process, the session began with standard instructions and explanations about the lesson's goal, the expected students' behaviors, and what the students will learn at the end of the class. The teacher explains how to use story maps and gives an example to the students. They were asked to focus on the teacher's explanation. The second is guided training. This process is similar to modeling stages. The students did the training, and the teacher only corrected errors by interrupting them. The next is testing. After all of the students had finished reading the story, they were given a task to complete the story maps. They have to submit their work to the teacher. After that, the teacher provides the comprehension questions to the students. The last is maintenance. Without using a graphic organizer, the teacher instructed the students to read the story and answer all of the questions during this process. 
In conducting research, the researcher found several related studies that discuss this topic. First, the previous study takes from a thesis. The thesis is entitled "The Effect of Story Maps of a Narrative Text toward the Reading Comprehension of Grade VIII Students of SMP N 9 Padang". The researcher used an experimental design to examine the performance of the students who use story maps and the students who do not use story maps. In conclusion, the use of story maps in the teaching and learning process positively impacts students' reading comprehension. Another study takes from an article titled "The Effect of Using Story Mapping Technique on Reading Comprehension Achievement of The Eighth Year Students at Mts. Negeri Bangsalsari." The researcher collected the data using the posttestonly Control Group Design. The final result showed a significant effect of using story maps on the reading comprehension achievement of the eighth-year students. The researcher also suggested the English teacher use story maps to improve students' reading comprehension.

The researcher wants to investigate students' perceptions on the use of story maps in reading comprehension in the class during the teaching-learning process. Based on the background of the study above, the researcher has created the following research questions:

1. What are students' perceptions on the use of story maps for reading comprehension in class?

2. What are the advantages of using story maps for students' reading comprehension in class?

3. What are the difficulties of using story maps for students' reading comprehension in class?

\section{METHOD}

The research design of this study used a qualitative research design. Qualitative research focuses on how the researcher sees society as a unique reality (Ary, Jacobs, Sorensen, et al., 2010). The researchers have to analyze the phenomena that happen near them. They are not only focusing on what people do but also on how they think and feel. The researcher used a descriptive qualitative design to describe the phenomena or facts in class in this research.

The participants of this study were tenth graders, which consisted of 31 students in one senior high school in Lamongan. The researcher chose this level because the teacher taught narrative text in this class, and she taught students using story maps. Second, according to the Indonesian curriculum, narrative text is in the tenth grade. Convenience sampling was used to select the participants.

The researcher obtained the data using a questionnaire and interview. The questionnaire was delivered after the students used story maps in reading class. The researcher distributed a questionnaire for 31 students to complete the questionnaire. The questions consist of several topics. The topics are students' perceptions on the use of story maps for reading comprehension in class, the advantages of using story maps for students' reading comprehension, and the difficulties of using story maps for students' reading comprehension. Then, the researcher used the interview to know more depth and strengthen students' responses in the questionnaire. The researcher interviewed nine students to clarify their answers. Students responded to the questionnaire and interview in the Indonesian language, and then the researcher translated them into English. 
According to Miles \& Huberman (1944), the data is analyzed by using three stages. Those are data reduction, data display, and conclusion drawing. In data reduction, the researcher collects a lot of data, so it is necessary to reduce the data to get a clear representation and make it easier to analyze. The researcher showed the data in the data display because it was easier to interpret what was happening and planned the following task according to something understood. After displaying the data, the researcher attempted to describe the data. Then, the researcher interpreted the findings in the form of systematic classification. The last is the conclusion drawn. In this stage, the researcher concluded about the use of story maps in reading comprehension for tenth graders.

\section{RESULTS AND DISCUSSION}

\section{Students' Perceptions on the Use of Story Maps for Reading Comprehension in Class}

The researcher used several questions in the questionnaire and interview to know the answer to the first research question, which was about students' perception when using story maps for reading comprehension in class. The questions were intended to know students' perceptions when using story maps for reading comprehension.

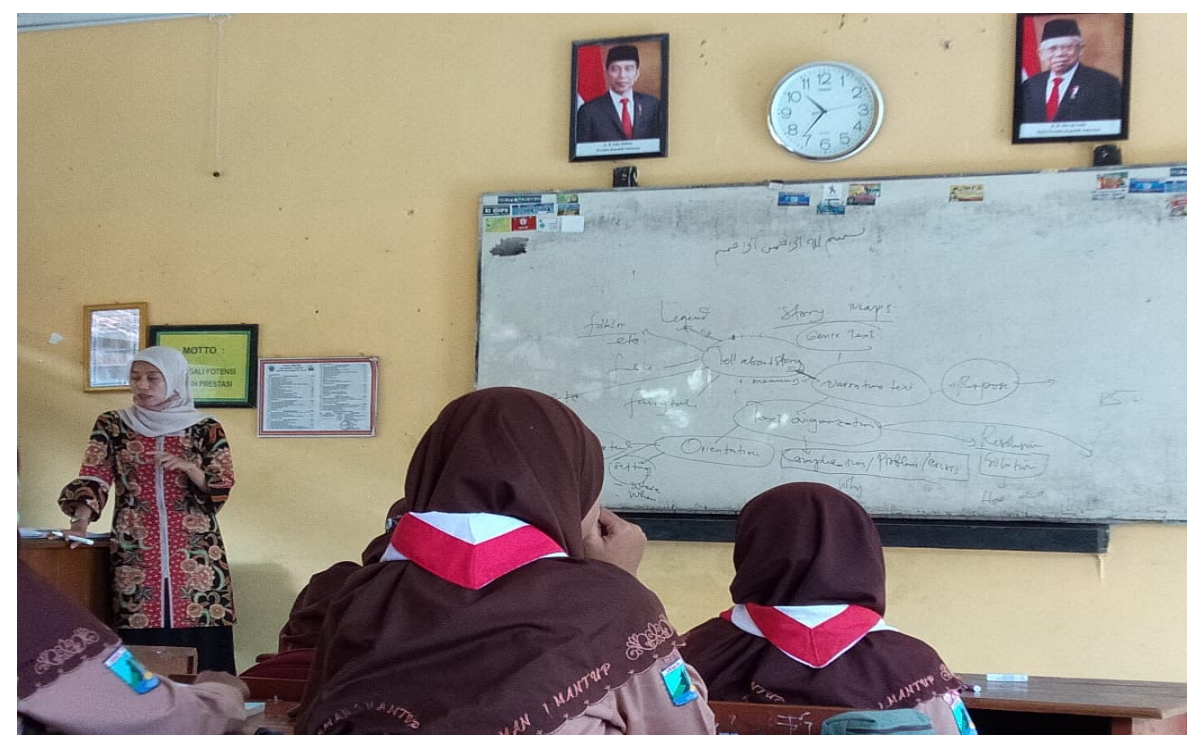

Figure 1. Teacher's explanation about story maps

The researcher wanted to know whether story maps could help students understand the text or not. Based on the question given to the students, most of them stated in the questionnaire that story maps helped them understand the text. There were several reasons why the students felt helpful when using story maps. First, it is easy to understand the text and material. Here are the students' responses:

A: Yes, it can help because in story maps the material given is easier to understand. B: It makes the material easy to learn.

Second, the students felt helpful when using story maps because story maps only show the critical points. Here are some students' responses: 
A: Yes, it was easy to learn because it only discusses the important points.

B: It can, it was easy to study and I only wrote the points.

C: Yes, story maps can help our learning activity. Because in story maps we only write the important points, so we do not need to read the whole text.

D: In my opinion story maps was helpful for me in the term of understood the text, because story maps only show the important points that already classified into structured part to make it easy to understand.

The third reason was they felt helpful in understanding the text using story maps because it classified the material into some parts and structures. Here are some students' responses:

A: Yes, because it divided the material into some parts.

B: Yes, because story maps have already been classified into some parts and structures.

C: Yes, because it was divide into all parts/structures that can be understood from the text when looking for answers or something from the story.

D: Yes, because it has already been classified into a structured part.

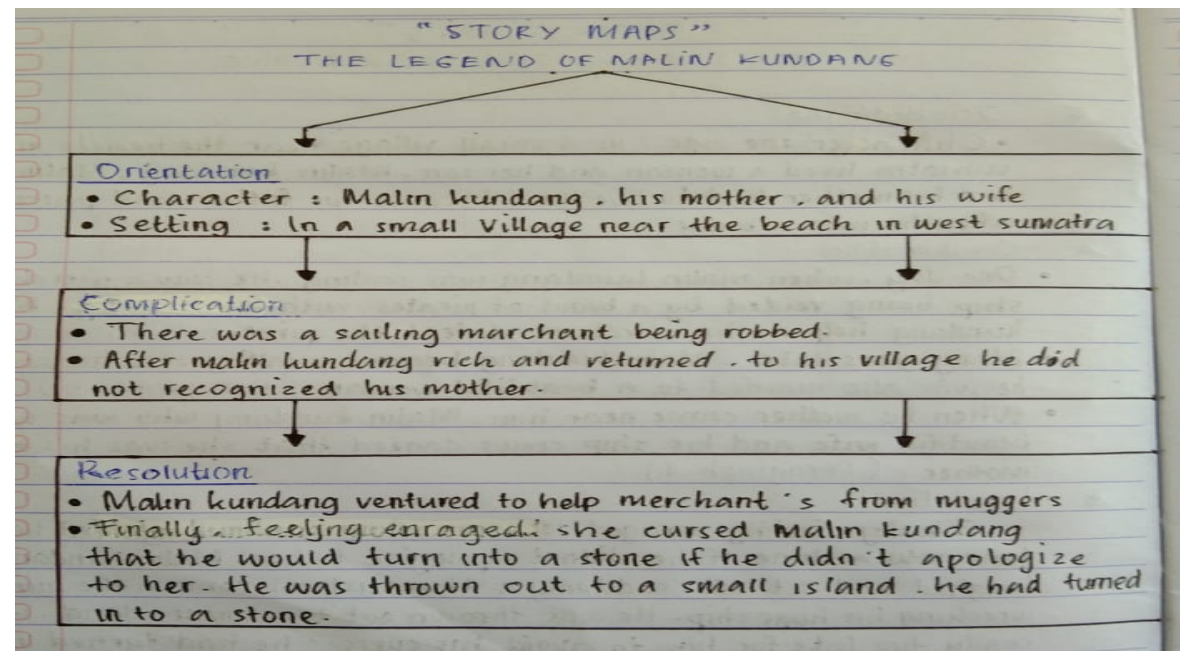

Figure 2. Student's story maps in the classroom

Next, the researcher asked the students whether there was an improvement in students' reading comprehension when using story maps. Most students responded that they got an improvement in reading comprehension by answering it for several reasons. First, the students felt it easy and fast to understand the text. Some students give an explanation on questionnaire and interview about it as follow:

A: Yes, it was fast to know the content of the text.

B: Yes, because with story maps, I who have difficulty in understanding the text can easily understand the text.

C: Yes, because it was fast to know the content of story maps.

D: Yes, because it was fast to know the content of the story maps, because without reading the whole text that maybe not have been read.

Second, story maps helped the students understand the structure of the text. 
Here are some students' responses:

A: Yes, there was an improvement. I can understand the structure of the text

B: Yes, because when using story maps I who sometimes don't understand the text can understand the text easier. By using story maps, I can divide the structure of the story into story maps.

Third, the students felt there was an improvement because they did not feel bored when using story maps. Here are some students' responses:

A: Yes, with story maps it makes us not bored in reading.

B: Yes, if we make story maps we're not felt bored.

Next, the researcher asked the students whether using story maps in understanding the text was an exciting activity or not. Most students stated that using story maps in the classroom was an exciting activity. There were several reasons why the students felt that using story maps was an exciting activity. First, the students felt that using story maps was interesting and not boring. Some students give an explanation on questionnaire and interview about that as follow:

A: Yes, because the shape is very interesting so I am not bored.

B: Yes, because when we read the story maps, there were interesting things.

C: Yes, it was interesting and not boring.

D: Yes, because before we make story maps we have to understand and pay attention to the text first, then we write it in story maps which is interesting and as creative as possible.

E: In my opinion, it was interesting because usually the appearance of story maps is interesting, usually it was made and designed as attractive as possible to make the reader interested and not bored when reading.

Second, the students said that story maps was unique. It could increase students' reading interest. Here are some students' responses:

A: Yes, because it was displayed in a unique and interesting concept.

B: Yes, in my opinion, the use of story maps was an interesting activity. Because usually I only read the story just like usual. It was interesting activity because it only shows the components of the story uniquely in story maps.

$\mathrm{C}$ : Yes, because story maps was displayed in a unique design or concept to make the reader interested.

Third, the students also stated that the use of story maps was interesting depending on what kind of activity the students did and when they created it. Here are some students' responses:

A: It depends on when we make the story maps.

B: It depends on the learning activity.

The Advantages of Using Story Maps for Students' Reading Comprehension in Class

To know the answer to the second research question, the researcher asked the students about the advantages of story maps. The first was they could easily 
understand the text. Several students give responses as follow:

A: Some advantages that I got when I used story maps, I can understand easily the text from the story, and because the shape is interesting I don't feel bored, and last I can easily read the text.

B: Interesting, it was fast to understand the text.

$\mathrm{C}$ : We can understand the structure and the content of the text faster.

Second, the students said that the use of story maps was interesting and not boring. Here are some students' responses:

A: It was easy to understand, more interesting.

B: I can understand more than if I don't use the story maps.

C: I'm not bored when reading, it was more interesting.

Third, students felt that story maps was not complicated and clear. Some students explained about it as follow:

A: It is easy to understand the text, the shape was interesting, the way how to understand the text was brief.

B: It was not complicated.

C: More presentable and clear.

D: The advantages that I got from story maps, I can make the story that I already read become clear, more detailed, and not complicated because I wrote the story in story maps.

\section{The Difficulties of Using Story Maps for Students' Reading Comprehension in Classroom}

To know the answer to the last research question, the researcher asked the students about the difficulties of using story maps for understanding the text. Most students stated that they did not have any problems when using story maps. Story maps was beneficial for them because it made them understand the text easily. However, several students faced some difficulties using story maps. First, they said that it was challenging to create story maps. Some students explained it as follow:

A: Yes, sometimes we make it not in order when making the design.

B: Yes, it was difficult to make story maps.

C: Sometimes we need more space when we make a story maps.

D: There was no difficulty in reading, but I have difficulty when creating the story maps. I need more space and because of that my story maps look less attractive.

Second, one student also stated that it was difficult for her to use story maps if she did not understand the concept of story maps. Here is the response:

A: For the difficulty yes there was a difficulty, maybe it can from the concept that less supportive or the story have less detailed that makes it difficult to understand.

Third, the students stated that if they could not understand the text, they would have problems making story maps. Some students explained it as follow:

A: If I do not understand the text carefully, so it makes me confused about the 
process of using story maps.

B: I often find difficulty when I cannot understand the structure of the text because in my opinion, it was not an easy thing to think about.

The finding above showed that the use of story maps for students' reading comprehension was beneficial. The students felt helpful when using story maps because of several reasons. Story maps helped them in understanding the text and the material because it only showed the essential points. According to Boulineau et al. (2004), story maps attract students' attention to important parts of stories, such as characters, time, setting, and plot, and use a specific structure to display important information in narrative text visually. In addition, Chang \& Chen (2002) say that by mapping text, students as readers have a guide to reading and finding focus points from the text to save time. The other reason was it classified the material into some parts and structures. Story maps divides the text into all parts or structures that can be understood from the text. Browder et al. (2015) explain that visual aids can benefit by displaying the story's structure more obvious and interesting.

Second, story maps made the students feel exciting in the class. In this study, the students thought that using story maps was an interesting activity. Sam \& Rajan (2013) state that the use of visual tools can make students who are proficient in comprehension find it easy and interesting to comprehend a text. In addition, students felt that story maps was not complicated and precise. Sam \& Rajan (2013) add that when a graphic organizer such as story maps united to represent the text's theme or topic, the material will be very clear to students.

Besides the advantages, the students also faced some difficulties when using story maps for understanding the text in class. The students stated that it was challenging to make story maps. They needed enough space to create story maps. If there was only a tiny space, it made their story maps look less attractive. The other students also said that if they could not understand the text, they would have difficulties creating story maps. Manoli \& Papadopoulou (2012) state that some students struggle with text comprehension, particularly when confronted with long passages. So if they could not understand the text first, they would have difficulty in making story maps.

\section{CONCLUSION}

The evidence suggests that the use of story maps reading comprehension is beneficial for the students. Most students feel that story maps help them understand the text. They feel helpful because story maps only show the critical points, so they can easily understand the text. Besides, it classifies the material into some parts and structures. The students also have an improvement in their reading comprehension. Most students agree that using story maps in the classroom is an exciting activity because story maps has a unique concept that makes them feel excited.

There are some advantages of using story maps for the students. It makes the reading material accessible and transparent so that the students can understand the text easily. Besides, using story maps in the classroom makes the students feel excited. They find that it is interesting. They can create their own story maps.

Lastly, the students face some difficulties using story maps. Some students need more space to create the story maps. If there is less space, it can make their 
story maps less attractive. Some of them cannot complete the story maps because they do not understand the text and the concept of the story maps. Based on the research results, the researcher suggests that teachers apply story maps in reading class to help students understand the text.

\section{REFERENCES}

Ary, D., Jacobs, L. C., \& Sorensen, C. K. (2010). Introduction to Research in Education (8th ed.). Wadsworth Cengage Learning.

Boulineau, T., Iii, C. F., Hagan-burke, S., \& Burke, M. D. (2004). Disability Quarterly. https://doi.org/10.2307/1593645

Browder, D. M., Root, J. R., Wood, L., \& Allison, C. (2015). Effects of a StoryMapping Procedure Using the iPad on the Comprehension of Narrative Texts by Students With Autism Spectrum Disorder. https://doi.org/10.1177/1088357615611387

Chang, K., \& Chen, I. (2002). The Effect of Concept Mapping to Enhance Text Comprehension and Summarization. 71(1), 5-23.

Isikdogan, N., \& Kargin, T. (2010). Investigation of the Effectiveness of the StoryMap Method on Reading Comprehension Skills among Students with Mental Retardation. 10(3), 1509-1527.

Jalilehvand, M. (2012). The effects of text length and picture on reading comprehension of iranian EFL students. Asian Social Science, 8(3), 329-337. https://doi.org/10.5539/ass.v8n3p329

Khodabandehlou, M., Jahandar, S., Seyedi, G., Mousavi, R., \& Abadi, D. (2014). The Impact of Self-directed Learning Strategies on Reading Comprehension. May.

Miles, Mathew B., \& A. Michael Huberman. (1994). An Expanded Sourcebook: Qualitative Data Analysis. London: Sage Publications.

Manoli, P., \& Papadopoulou, M. (2012). Graphic Organizers as a Reading Strategy: Research Findings and Issues. 3Manoli, P(3), 348-356.

Meniado, J. C. (2016). Metacognitive Reading Strategies, Motivation, and Reading Comprehension Performance of Saudi EFL Students. 9(3), 117-129. https://doi.org/10.5539/elt.v9n3p117

Qanwal, S., \& Karim, S. (2014). Identifying Correlation between Reading Strategies Instruction and L2 Text Comprehension. 5(5), 1019-1032. https://doi.org/10.4304/jltr.5.5.1019-1032

Sam, P. D. \& Rajan, P. (2013). Using Graphic Organizers to Improve Reading Comprehension Skills for the Middle School ESL Students. 6(2). https://doi.org/10.5539/elt.v6n2p155 